\title{
The Silver Coinage of Roman Syria Under the Julio-Claudian Emperors
}

\section{Kevin Butcher ${ }^{1}$ and Matthew Ponting ${ }^{2}$}

\begin{abstract}
Analyses of 71 Roman provincial silver coins of the Julio-Claudian emperors (27 BC-AD 68) minted at Caesarea in Cappadocia and Antioch and Tyre in Syria are discussed in this paper. The finenesses of the alloys are presented and it is proposed that there was a logical relationship between the standards used for Caesarea and Antioch. Trace element profiles and selected lead isotope analyses help to characterize the products of the different mints, and also demonstrate that one particular issue of coinage, normally attributed to a mint in Syria, was probably produced at Caesarea in Cappadocia. During this period minting of silver at Tyre was discontinued and trace elements suggest that some of the later Antiochene coinage may have been produced from recycled Tyrian silver.
\end{abstract}

Keywords: Roman, Antioch, silver, coins, analysis

This paper presents the results of the metallurgical analyses of 51 silver tetradrachms, two didrachms and one drachm of the Roman province of Syria, issued between 46/45 $\mathrm{BC}$ and $\mathrm{AD}$ 67/68; seven tetradrachms and one didrachm of Tyre, issued between 12 BC and $\mathrm{AD} 52$; and, for comparative purposes, nine silver coins of Caesarea in Cappadocia, issued between $c$. AD 17 and AD 65. These analyses form part of a wider programme investigating the background to the reform of the Roman imperial silver coinage under Nero (AD 54-68).

The coinages in question have been the subject of analyses before, by D. R. Walker, in 1976. His work, The Metrology of the Roman Silver Coinage, became the standard reference during the 1970s and 1980s for anyone seeking information about the fineness of Roman imperial and provincial silver. However, during the 1990s it became clear that Walker's results were faulty, because he had measured the silver content in the surfaces of the coins only (Butcher and Ponting 1995; 1998). These surfaces had been deliberately depleted of their copper content at the time of manufacture, after the blanks had been cast and prior to striking, and further depleted by natural

\footnotetext{
${ }^{1}$ Kevin Butcher, Department of Classics and Ancient History, University of Warwick, Coventry CV4 7AL, UK; email: K.E.T.Butcher@warwick.ac.uk; ${ }^{2}$ Matthew Ponting, School of Archaeology, Classics and Egyptology, University of Liverpool, Liverpool L69 3GS, UK; email: M.Ponting@ liverpool.ac.uk
}

processes during centuries of burial and the processes of cleaning after their discovery. This means that the surface compositions of most Roman silver coins are no longer representative of the original alloy used to manufacture the blanks (Gitler and Ponting 2003). Indeed, Walker's results vary considerably from coin to coin, even within single issues, giving an impression of inconsistency at the mint, but this is because of variations in the amount of copper depleted from the surfaces, not because the individual coin issues were originally produced from variable alloys. ${ }^{1}$ It is now becoming clear that the provincial silver coins were produced from strictly-controlled alloys of silver and copper and that the number of different standards in use at any one time was limited. It is the original alloy, preserved in the 'heart metal' of the coins' interiors, which must be analyzed in order to define these standards, which in turn allow us to speculate about fiscal policies and the relationship of different silver coinages to one another.

\section{Syrian Silver}

The silver coinage of Roman Syria was composed almost exclusively of large, thick coins weighing

\footnotetext{
${ }^{1}$ Walker attempted to overcome the problem of enrichment of silver at the surface by lightly abrading the edge of each coin until he obtained what he considered to be repeatable readings. These abrasions can still be seen on coins that he analyzed in the collections of the British Museum and Ashmolean Museum; in most cases they would have been insufficient to penetrate the depleted region.
} 
between about 14 and $15 \mathrm{~g}$, referred to in modern scholarship as tetradrachms (i.e. a denomination of four drachms). It is important to note that for most of the period examined here there were at least two discrete pools of circulation for Syrian tetradrachms: one in the north, dominated by the products of Antioch, which are the focus of this study; and another in the south, in Phoenicia, southern Syria and Palestine, dominated by the products of Tyre. The silver coinage of Tyre has already been touched upon in another of our articles (Butcher and Ponting 2005b): this coinage was almost pure silver bullion, unlike the tetradrachms of Antioch, and included substantial issues of didrachms as well as tetradrachms. Hoard evidence suggests that there was little or no overlap between these two pools of circulation, so that Tyrian products did not circulate in the north, and Antiochene products are absent from the south; and the coins from both pools did not circulate outside these regions, e.g. in Asia Minor or in Egypt.

These provincial silver issues from Antioch, Tyre and other subsidiary mints sufficed for the entire province of Syria. No other silver coinages circulated there. There is some limited evidence for the introduction of the Roman imperial denarius to the southern circulation pool in the Julio-Claudian period, but currently none whatsoever for the northern one (Butcher 1996, 101-2). But, when all of the evidence is taken into account, it seems unlikely that the denarius was a regular feature of circulation in either pool under the Julio-Claudians, at least until the reign of Nero and quite possibly later (see Butcher 2004, 192-95).

A major change to the Syrian silver coinage occurred towards the end of our period, during the reign of Nero. The Tyrian silver came to an end, and the entire region then came to be dominated by the Antiochene tetradrachms. Essentially it appears that the two circulation pools were united under a single standard, and all pre-Neronian issues were removed from circulation. This removal probably took several decades: hoards deposited in the 2nd century AD contain no coins earlier than the reign of Nero, but evidence for the period between Nero and Trajan is sparse (the process of removal of earlier coins, and the evidence, is described in Butcher 2004). The reign of Nero is therefore a watershed in the history of hoarding and circulation of Syrian tetradrachms, just as it is a watershed in the hoarding of Roman imperial denarii and Egyptian silver coinage. ${ }^{2} \mathrm{We}$

\footnotetext{
${ }^{2}$ For Egypt, see Christiansen 2004, 95-102.
}

propose that these hoarding patterns observed for the different silver coinages of the empire are connected, and that changes made to the silver content of Roman denarii, Syrian tetradrachms and Alexandrian tetradrachms under Nero are part of the same, empire-wide process of standardization and rationalization (Butcher 2004, 253-55; and Butcher and Ponting 2005b).

Much has been written about the standard used for the Neronian tetradrachms of Antioch (e.g. Walker 1976, 70-73). Ancient sources confirm that some tetradrachms were worth three denarii and others four, and Walker proposed that until Nero's reign both standards had been in use. According to him, the tetradrachms were always heavily overvalued against the denarius, with the rate of overvaluation fluctuating between reigns. In AD 59/60 Nero standardized the tetradrachm coinage at the rate of four denarii, and thereafter no three-denarius tetradrachms were issued in Roman Syria, except for one anomalous group of coins bearing portraits of Nero and Divus Claudius with Latin rather than the normal Greek legends (Walker 1976, 70-73; see below).

Another change that occurred to Antiochene silver in the reign of Nero was typological. A new reverse type, not previously used on the Antiochene tetradrachm, appeared in Nero's reign: a standing eagle with wings spread. A similar eagle, with wings closed, had been the standard reverse type for Tyre, and it has been proposed that the new Neronian coins effectively bore a 'Tyrian' type to announce that they were 'good silver of the Tyrian stamp' (such phrases are known from texts: Walker 1976, 70). In this way the Neronian tetradrachms valued at four denarii replaced the Tyrian.

Hoard evidence confirms Walker's general conclusion that Nero's new 'eagle' tetradrachms replaced Tyrian silver in the south (Butcher 2004, 180-81), but in the north the picture is less clear, largely because there are few recorded hoards from that region. Indeed, no hoards containing Antiochene silver minted under Tiberius, Caligula, Claudius or Nero (prior to $\mathrm{AD} 59 / 60$ ) have been recorded at all and, until they are, the circulation pattern of these coins, and any clues as to the processes by which they were removed from circulation, will remain enigmatic. It seems likely that the picture was broadly similar to that in the south: in what little hoard evidence we have from the north for the 2nd century $\mathrm{AD}$ the sequence of issues always begins with Nero's 'eagle' tetradrachms. However, it should be noted that many of the surviving specimens of tetradrachms of 
Caligula, Claudius and Nero prior to AD 59/60 are very worn, suggesting that they circulated for some considerable time (how long is, of course, debatable, but they sometimes exhibit wear as heavy as Neronian 'eagle' tetradrachms found in mid to late 2nd-century hoards). It may prove the case that these 'absent' silver coinages continued to circulate in a very confined region of Syria; as we will see, there are good reasons to view these pre-59/60 coinages as different from most of the other issues examined here.

In this study we have concentrated on the products of the mint of Antioch, which was the only mint to issue substantial quantities of tetradrachms in this period. Smaller coinages may be noted at Seleucia Pieria (RPC I, 4328-29) and Laodicea (RPC I, 4381$85)$ under the Julio-Claudians. In addition, a series of coins with the reverse type of a seated figure of Zeus was issued at an uncertain mint in northern Syria or Cilicia Pedias between the reigns of Augustus and Claudius (RPC I, 4108-21). No specimens of these coinages were available for analysis. However, a specimen of the substantial tetradrachm coinage with Latin legends for Nero and Divus Claudius (RPC I, 4122-23), from an uncertain mint, was analyzed; as will be seen, the results provide a solution to the puzzle of where this coinage was struck.

\section{Cappadocian Silver}

The coinage of Caesarea in Cappadocia consisted mainly of didrachms and drachms, with occasional (though often substantial) issues of hemidrachms. As will become apparent below, it is likely that the mint was also involved in the production of tetradrachms on one occasion.

Surprisingly little is known about the circulation of the silver coinage of Caesarea. It appears to have been confined mainly to Anatolia and did not circulate in Syria, although the coins have also been found further east and north, e.g. in Colchis. ${ }^{3}$ From the hoards of Caesarean coins that have been published it appears that once again the reign of Nero formed a watershed in hoarding patterns. Most 2nd-century hoards begin with the issues of Vespasian (AD 69-79). ${ }^{4}$

Some of our previous work examined the silver standard employed at Caesarea from Vespasian (AD 69-79) to Hadrian (AD 117-38): the coins were all produced from a 50:50 silver/copper alloy (Butcher

\footnotetext{
${ }^{3}$ Abramzon 2003.

${ }^{4}$ The notable exception is the hoard recorded by Baldwin (1927), which closed with Hadrian and included Julio-Claudian issues as well as some coins of Archelaus, the last king of Cappadocia (see RPC I, 551). But other 2nd-century hoards begin with Vespasian.
}

and Ponting 1995, 1997, 1998). Recent work has shown that this standard continued at Caesarea under Commodus and, with a very slight reduction in silver content (to about 46\%), under Septimius Severus (Gitler and Ponting 2003). A fairly consistent standard was therefore employed for at least a century, but nothing was known of the silver standard(s) used under the Julio-Claudian emperors.

Walker considered the Caesarean drachm to be equal in value to a denarius throughout the entire period, regardless of changes to the fineness of the coinage. However, in an article published in 1992 and using Walker's data, one of the authors of the present article proposed that from Vespasian onwards the Caesarean drachm was equal to three-quarters of a denarius, a standard known from metrological writings and often referred to as the 'Rhodian' or 'Antiochene' standard. ${ }^{5}$ The proposal seems not to have gained any acceptance among numismatists, who continue to insist on the equivalence between the denarius and the Caesarean drachm, ${ }^{6}$ but a change in fineness and value between the Julio-Claudians and Vespasian might perhaps explain the dominant hoarding patterns.

Most of the Caesarean issues of the JulioClaudians have Latin legends, which is presumably why these provincial silver coins have traditionally been included in catalogues of Roman 'imperial' coinage. Although the standard type on the coinage of Caesarea in Cappadocia, an image of Mount Argaeus (Erciyes Dagi in Central Turkey) is common from the Flavian period onwards, it is not found very often in the Julio-Claudian period. Most of the issues bear dynastic types or commemorative designs which have a stronger affinity with Roman imperial issues.

\section{The Coins Analyzed}

There is always the danger that in being compelled to analyze a significant number of low-grade coins (better-grade coins being judged too aesthetically important to be sampled) there will be some ancient forgeries among the material. This was indeed the case with the tetradrachms of Roman Egypt (where one coin turned out to be made of leaded bronze: Butcher and Ponting 2005b, 103) and it seems to be the case with one of the Syrian tetradrachms analyzed here (P57: see below, no. 17). In addition, several of the coins analyzed here (nos E1, A27, KB4) have been chemically stripped in modern times. This

\footnotetext{
5Butcher 1992; on the 'Rhodian' and 'Antiochene' standards, Butcher 2004, 199, 254.

${ }^{6}$ RPC II, 22; Weiser and Cotton 1996, 262.
} 
results in the further leaching of copper from throughout the coin, so that these coins are useless for estimates of silver content, giving results that are too high. ${ }^{7}$ However, they remain useful for trace elements associated with the silver and can therefore contribute to debates about provenance and technology.

\section{Syria}

\section{'Posthumous Philips'}

The first silver coinage of Roman Syria consisted of tetradrachms imitating the issues of the Seleucid king Philip Philadelphus (93-83 BC). ${ }^{8}$ These bear Philip's portrait on the obverse and a seated figure of Zeus on the reverse, together with Philip's name and titles. The earliest issues (c. 57-51 BC) bear monograms of Roman governors' names in the right-hand field before the figure of Zeus, but from year 3 of the Antiochene Julian era (47/46 BC) the coins bear dates and a single monogram which could be expanded as either ATX or AYT and until recently was interpreted to mean either ANTIOXE $\Omega N$ or AYTONOMOY. Thanks to the recent identification of a group of slightly earlier, pre-Roman, tetradrachms that are marked with two monograms (this one and another which is clearly an abbreviation of AYTONOMOS or AYTONOMOY), ${ }^{9}$ there can be little doubt about the reading of the monogram as ATX, an abbreviation of the city's name or ethnic. The last of the coins of this class analyzed appears to be dated year 36 of the Antiochene Julian era (14/13 $\mathrm{BC})$.

\section{Augustus}

The first Antiochene tetradrachms to bear the portrait of Augustus continue the seated Zeus reverse type of the posthumous Philip coinage. These coins, which are dated by Augustus' twelfth consulship, belong to $5 \mathrm{BC}$. They were followed by another issue bearing the reverse type of the Tyche of Antioch seated on a rock and holding a palm branch, with the river Orontes swimming at her feet. This series of 'Tyche' tetradrachms begins in Augustus' twelfth consulship and year 26 of an Actian era (5 BC), and continues down to what is almost certainly a posthumous issue struck in AD 14 (RPC I, 4160).

The Tyche coins have been noted in hoards of posthumous Philips (Butcher 2004, 87).

\footnotetext{
${ }^{7}$ See Woytek et al. 2007, 152 for a discussion of the effects of extreme leaching of copper on denarii of Trajan.

${ }^{8}$ Newell 1919. See also McAlee 1999 and Butcher 2004, 51-54.

${ }^{9}$ Hoover 2004.
}

\section{Tiberius}

Some rare 'Tyche' tetradrachms issued at Antioch under Tiberius are known (RPC I, 4162). None were available for analysis.

\section{Caligula}

The tetradrachms of Caligula are dated by regnal years, from 1 ( $\mathrm{AD} 37)$ to $3(\mathrm{AD} 38 / 39)$ and bear portraits of his mother Agrippina on the reverse. Two of these were available for analysis.

\section{Claudius}

The Antiochene silver coinage of Claudius is very rare, apart from an issue of silver didrachms in the name of Nero marked $\triangle \mathrm{I} \triangle \mathrm{PAXMON}$ (RPC I, 4171). ${ }^{10}$ The didrachm denomination had not previously been issued. A single coin, a didrachm of Agrippina and Nero, was available for analysis.

\section{Nero}

Issues of Antioch

There are clearly two phases to the Antiochene issues of Nero. The first seems to belong with the earlier coinages of Caligula and Claudius, and is absent from later hoards. Like the coinages of Caligula and Claudius it bears dynastic types: Nero and Divus Claudius, and Nero and Agrippina, as well as the $\triangle \mathrm{I} \triangle \mathrm{PAXMON}$ type found under Claudius. ${ }^{11}$ As will become apparent, the silver standard used for these coins also places them with the issues of Nero's immediate predecessors and separates them from his later coinage.

The second Neronian phase comprises several different issues in different styles. The earliest tetradrachms are dated using two systems, from regnal year 6/Caesarean Antiochene year 108 to regnal year 8/Caesarean year 110 (AD 59/60-61/62; RPC I, 4180-82). These coins all have the reverse eagles facing left. There then follows a series with right-facing eagles, dated Antiochene year 111 and regnal years 9-10 (AD 62-63; RPC I, 4184-86, together with the drachm 4187). This is followed by issues with a more mature portrait of Nero dated Antiochene year 112 and regnal year 10, also with eagles facing right (RPC I, 4188-90). Finally there is another group with mature portraits and eagles

\footnotetext{
${ }^{10}$ During the reigns of Claudius and Nero small denominations, in the form of didrachms and drachms, were issued at Antioch, but these were uncommon and presumably unfamiliar to users, so that the issuers felt the need to place value marks on many of them (DIDRACMON and DRACMH: see nos 21,23 and 24 below). Denominational marks are very rare on Greek and Roman coins, and such explicit inscriptions, rather than abbreviations, are virtually unique on silver.

${ }^{11}$ Prieur and Prieur 2000, 12-13, nos 73-75A, 77-78; Butcher 2004, 6468.
} 
facing left, dated by the Antiochene era only (RPC I, 4191-92).

We have proposed that the intended weight of the Neronian tetradrachms of Antioch is about 14.8 g. ${ }^{12}$

Tetradrachms of Nero and Divus Claudius ( RPC I, 412223)

These coins are unlike other Syrian tetradrachms in style, and have Latin legends rather than Greek (RPC I, 556-57, 605). However they are very like a group of didrachms and drachms attributed to Caesarea in Cappadocia, having similar legends, identical types and styles - so much so that the tetradrachms were assigned to Caesarea by Sydenham (1933, 36). Walker $(1976,69)$ argued that they were produced in Syria, on the grounds that their fineness was different to the Caesarean coins and that the tetradrachm is not otherwise a Caesarean denomination'. The denomination would certainly be unique for Caesarea, which normally issued didrachms, drachms and hemidrachms. Gilmore (1980) argued that they were produced in Syria by mint workers from Caesarea, and Butcher (2004, 68-69) suggested that they were minted at Caesarea for use in Syria. If Syrian, they are elusive in Syrian hoards, which often contain large numbers of Antiochene 'eagle' tetradrachms of Nero. Single specimens have been recorded in Syrian hoards, but these are all of mid 2nd- to 3rd-century date. ${ }^{13}$ Three of these hoards contain no Antiochene 'eagle' tetradrachms of Nero; whether that is significant or not must await further evidence. However, metal analysis provides fairly conclusive proof of where these coins were made, if not where they circulated (see below).

\section{List of Syrian Coins Sampled}

Antioch, Syria

Pre-Imperial 'Posthumous Philip' Tetradrachms

Obv: Diademed head of Philip Philadelphus right. Fillet border. Rev: BA $\Sigma \mathrm{I} \Lambda \mathrm{E} \Omega \Sigma$ ФІ $\Lambda$ IППОY ЕПIФАNOY $\Sigma$ ФI $\Lambda \mathrm{A} \Delta \mathrm{E} \Lambda \Phi O Y$, Zeus seated left on throne, holding Nike and sceptre, Antioch monogram before; date in exergue.

1. Sample KB5. Year 4, 46/45 BC, RPC I, 4128.

2. Sample KB6. Year 4, 46/45 BC, RPC I, 4128.

3. Sample KB7. Year 10, 40/39 BC, RPC I, 4133.

4. Sample A18. Year 19, 31/30 BC, RPC I, 4136. Walker 1976, no. 592 ( $71 \%$ fine).

\footnotetext{
${ }^{12}$ Butcher and Ponting 2005, 114.

${ }^{13}$ Butcher 2004, 273, no. 29 (allegedly from Latakia, ending with tetradrachms of Hadrian, AD 117-38); 274, no. 35a (allegedly from the region of Banias, south of Latakia, possibly ending with coins of Marcus Aurelius, AD 161-80); 275, no. 38a (ending with tetradrachms of Elagabalus, AD 218-22); 275 , no. 38b (also ending with Elagabalus).
}

5. Sample KB8. Year 19, 31/30 BC, RPC I, 4136.

6. Sample KB9. Year 20, 30/29 BC, RPC I, 4137.

7. Sample A19. Year 21, 29/28 BC, RPC I, 4138. Walker 1976, no. 594 (69\% fine).

8. Sample A20. Year 28, 22/21 BC, RPC I, 4144. Walker 1976, no. 603 (68\% fine).

9. Sample KB10. Year 28, 22/21 BC, RPC I, 4144.

10. Sample A21. Year 36, 14/13 BC. Not in RPC, Prieur or CRS; see McAlee 1999. Walker 1976, no. 609 (70\% fine).

\section{Augustus}

Obv: $\Sigma$ EBA $\Sigma$ TOY YП IB, bare head right. Rev: KAI $\Sigma A P O \Sigma$ OEOY YIOY, Zeus seated left on throne, holding Nike and sceptre, monograms before and in exergue. RPC I, 4150.

Tetradrachm, 5 BC.

11. Sample A22, CRE 733 (this coin). Walker 1976, no. 615 (70\% fine).

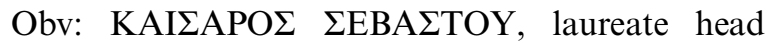
right. Rev: ETOY $\Sigma$ [date] NIKH $\Sigma$; Tyche of Antioch seated right on rock, holding palm branch; river god Orontes swimming at her feet. In field, YПА IB and Antioch monogram.

Tetradrachms.

12. Sample A23, Actian year 26, 5 BC, RPC I, 4151. Walker 1976, no. 618 (88.5\%).

13. Sample A24, Actian year 27, 5/4 BC, RPC I, 4152, CRE 734 (this coin). Walker 1976, no. 620 $(82 \%)$.

14. Sample P51, Actian year $27,5 / 4$ BC, RPC I, 4152.

15. Sample P52, Actian year $28,4 / 3$ BC, RPC I, 4153.

As previous, but reverse YПА IГ.

16. Sample P54, Actian year 29, 2 BC, RPC I, 4155.

As previous, but reverse legend ANTIOXE $\Omega N$ MHТРОПО $\Lambda$ E $\Omega$, with dates and Antioch monogram in field.

17. Sample P57, Actian year 36, Caesarean 54, AD 6, RPC I, 4158.

18. Sample A25, Actian year 42, Caesarean 60, AD 12, RPC I, 4159, CRE 1435 (this coin). Walker 1976, no. $627(86 \%)$.

\section{Caligula}

Obv: ГAIOY KAI $\Sigma$ APO $\Sigma \Sigma$ EBA ГЕPMA, laureate head right. Rev: АГРIППЕINH $\Sigma$ ANTIO MHTPO, draped bust of Agrippina right; before, ET [ + date].

Tetradrachms.

19. Sample E1, Regnal year 2, AD 37/38, RPC I, 4166 (dot in field).

20. Sample A26, Regnal year 3, AD 38/39, RPC I, 4167. Walker 1976, no. $634(55 \%)$. 
Claudius

Obv: АГРІППЕINHC CЕВАСТНС, draped bust of Agrippina left. Rev: NEPWNOC KAICAPOC ГEPMANIKOY, draped bust of Nero left. RPC I, 4170.

Didrachm, AD 50-54.

21. Sample A27.

Nero

First phase

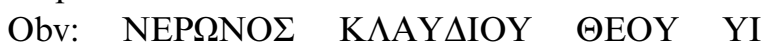
KAI $\Sigma A P O \Sigma \Sigma E B$, laureate head right. Rev: $\Theta E O Y$ $\mathrm{K} \Lambda \mathrm{AY} \triangle \mathrm{IOY}$, laureate head of Claudius right; before neck, Г/EP. RPC I, 4174.

Tetradrachm, Regnal year 3 and Caesarean year 105, AD 56/57.

22. Sample E3.

Obv: NEP $\Omega$ NO $\Sigma$ KAI $\Sigma$ APO $\Sigma \Sigma E B A \Sigma T$, laureate head right. Rev: $\triangle \mathrm{I} \triangle \mathrm{PA} X \mathrm{MON}$ lituus and simpulum; below, ЕРГ. RPC I, 4178.

Didrachm, Regnal year 3 and Caesarean year 105, AD 56/57.

23. Sample A28. Walker 1976, no. 644 (58.5\%).

Obv: NEPQNO $\Sigma$ KAI $\Sigma A P O \Sigma \quad \Sigma E B A$, laureate head right. Rev: $\triangle \mathrm{PAXMH}$, tripod with snake entwined around it; above, ЕРГ. RPC I, 4179.

Drachm, Regnal year 3 and Caesarean year 105, AD 56/57.

24. Sample A29. Walker 1976, no. 647 (74\%).

Second phase

Obv: NEP $\Omega N O \Sigma$ KAI $\Sigma$ APO $\Sigma$ $\Sigma$ EBA $\Sigma T O Y$, laureate bust right, with aegis. Rev: Eagle standing left on thunderbolt, wings spread; in field to left, palm branch; in field to right, date.

Tetradrachms.

25. Sample KB11. Regnal year 6, Caesarean year 108, AD 59/60. RPC I, 4180.

26. Sample B468. Regnal year 6, Caesarean year 108, AD 61/62. RPC I, 4180.

27. Sample A30. Regnal year 7, Caesarean year 109, AD 60/61. RPC I, 4181. Walker 1976, no. 654 $(77 \%)$.

28. Sample KB12. Regnal year 7, Caesarean year 109, AD 60/61. RPC I, 4181.

29. Sample P81. Regnal year 7, Caesarean year 109, AD 60/61. RPC I, 4181.

30. Sample A31. Regnal year 8, Caesarean year 110, AD 61/62. RPC I, 4182. Walker 1976, no. 658 $(73 \cdot 5 \%)$.

31. Sample KB13. Regnal year 8, Caesarean year 110, AD 61/62. RPC I, 4182.

32. Sample KB14. Regnal year 8, Caesarean year 110, AD 61/62. RPC I, 4182.
33. Sample P82. Regnal year 8 , Caesarean year 110, AD 61/62. RPC I, 4182.

34. Sample B466. Regnal year 8, Caesarean year 110, AD 61/62. RPC I, 4182.

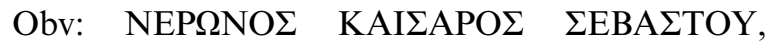
laureate bust right, with aegis. ETOY $\Sigma$ AIP. $\Theta$. Eagle standing right on thunderbolt, wings spread; in field to right, dot and palm branch. RPC I, 4184.

Tetradrachm, Regnal year 9 and Caesarean year 111, AD 62/63.

35. Sample KB15.

36. Sample P84.

Obv: NEP $\Omega N$ KAI $\Sigma A P ~ \Sigma E B A \Sigma T O \Sigma$, laureate bust right, with aegis. Rev: AIP. $\Theta$. Eagle standing right on thunderbolt, wings spread; in field to right, dot and palm branch. RPC I, 4185.

Tetradrachms, Regnal year 9 and Caesarean year 111, AD 62/63.

37. Sample KB16.

38. Sample B462.

39. Sample A32.

40. Sample P85.

Obv: NEP $\Omega$ N KAI $\Sigma A P$ EEBA $\Sigma T O \Sigma$, laureate bust right, with aegis. Rev: ETOY $\Sigma$ AIP I. Eagle standing right on thunderbolt, wings spread; in field to right, dot and palm branch. RPC I, 4186.

Tetradrachms, Regnal year 10 and Caearean year 111, AD 63.

41. Sample KB17.

42. Sample P87.

Obv: NEP $\Omega$ N KAI $\Sigma$ AP $\Sigma$ EBA $\Sigma T O \Sigma$, laureate bust right, with aegis. Rev: ETOY $\Sigma$ BIP I. Eagle standing right on thunderbolt, wings spread; in field to right, palm branch. RPC I, 4189.

Tetradrachms, Regnal year 10 and Caesarean year 112, AD 63/64.

43. Sample A33. Walker 1976, no. 677 (84.5\%).

44. Sample KB18.

Obv: NEP $\Omega$ N KAI $\Sigma$ AP $\Sigma$ EBA $\Sigma T O \Sigma$, laureate bust right, with aegis. Rev: ETOY $\Sigma$ BIP I. Eagle standing right on thunderbolt, wings spread; in field to right, dot and palm branch. RPC I, 4190.

Tetradrachms, Regnal year 10 and Caesarean year 112, AD 63/64.

45. Sample KB19.

46. Sample P90.

Obv: NEP $\Omega$ N KAICAP CEBACTOC, laureate bust left, with aegis. Rev: ETOYC $\triangle I P$. Eagle standing left on club, wings spread; in field to left, palm branch. RPC I, 4191.

Tetradrachms, Caesarean year 114, AD 65/66.

47. Sample A34. Walker 1976, no. 684 (72\%).

48. Sample KB20. 
49. Sample P91.

50. Sample B473.

Obv: NEPSN KAICAP CEBACTOC, laureate bust right, with aegis. Rev: ETOYC SIP. Eagle standing left on wreath, wings spread; in field to left, palm branch. RPC I, 4192.

Tetradrachms, Caesarean year 116, AD 67/68.

51. Sample P92.

52. Sample B474.

53. Sample H2.

\section{Uncertain Mint}

Obv: NERO CLAVD DIVI CLAVD F CAESAR AVG GER, laureate head right, star behind. Rev: DIVOS CLAVD AVG GERMANIC PATER AVG, laureate head of Claudius right. RPC I, 4123.

Tetradrachm, c. AD 63-68.

54. Sample A17. Walker 1976, no. 694 (56\%).

\section{Tyre}

The silver coinage of Tyre has been the subject of a number of recent articles by Levy (1993, 1995, 2005). The coinage of tetradrachms and didrachms began in the first year of Tyre's 'liberation' from the Seleucids $(126 / 125$ BC) and continued more or less unbroken until the reign of Nero. The basic types, Head of Heracles (Melkart)/Eagle standing left, remained the same throughout the life of this series. In year 109 $(18 / 17 \mathrm{BC})$ the letters KP or KAP appear in the upper left-hand field of the reverse, and continue on the coins down to the end of the series. ${ }^{14}$ Levy has also noted that the later coins of the KP series consistently bear the monograms CAP or EPH (?) beneath KP as well. What these letters mean is unclear; Weiser and Cotton $(2002$, 240) have proposed that KP is a continuation of the reverse legend (see below) and that it be expanded to KATA P $\Omega$ MAIOY $\Sigma$. Other interpretations have been proposed (Meshorer 2001, 76; Lönnqvist 2007, 20). The notion that the introduction of KP marks the transfer of production of Tyrian silver from Tyre to Jerusalem should be rejected; there seems to be no reason to attribute coins with the reverse inscription 'of Tyre, the sacred, the inviolate' to any other place than Tyre itself. ${ }^{15}$

The Tyrian coins were produced on a different weight standard to those of Antioch. We have suggested elsewhere that the intended weight of the KP tetradrachms is about $14 \cdot 1 \mathrm{~g}$ (Butcher and Ponting 2005b, 112).

\footnotetext{
${ }^{14}$ There is, however, evidence that the letters first appeared intermittently, and make their first appearance as early as 24/23 BC (Lönnqvist 2007, 20).

${ }^{15}$ Levy 1995; see also the comments in RPC I, 655-56, and Lönnqvist 2007, 19-20.
}

\section{List of Tyrian Coins Sampled}

Obv: Laureate head of Heracles right. Rev: TYPOY IEPA $\Sigma$ KAI A $\Sigma Y \Lambda O Y$, eagle standing left on prow of galley, with palm on wing; in field before, date and inverted club; behind, KP and monogram.

55. Sample A35, RPC I, 4645, CRE 1495 (this coin). Tetradrachm, year 115 (12/11 BC). Walker 1976, no. $576(95 \cdot 25 \%$ fine $)$.

56. Sample A37, RPC I, 4647, CRE 1496 (this coin). Tetradrachm, year 117 (10/9 BC). Walker 1976, no. 577 (94\% fine).

57. Sample A36, RPC I, 4657. Tetradrachm, year 144 (AD 18/19).

58. Sample KB22, RPC I, 4657. Tetradrachm, year 144 (AD 18/19).

59. Sample KB23, RPC I, 4658. Tetradrachm, year 145 (AD 19/20).

60. Sample KB24, RPC I, 4693. Didrachm, year 159 (AD 33/34).

61. Sample A38, RPC I, 4665. Tetradrachm, year 161 (AD 35/36). Walker 1976, no. 580 (94\% fine).

62. Sample A39, RPC I, 6476. Tetradrachm, year 177 (AD 51/52).

\section{Cappadocia}

The number of coins of Caesarea in Cappadocia available for analysis was limited, and what follows can hardly be described as a comprehensive sweep of the series.

\section{Tiberius}

There are two main groups of issues for Tiberius, the earliest with Greek legends (RPC I, 3620), and the later one with Latin legends (RPC I, 3621-22). The Greek issues bear the reverse type of Mount Argaeus, which became a standard Caesarean type in the postJulio-Claudian period. The Argaeus type was employed again towards the end of Nero's reign, on an issue of didrachms and drachms which combine Latin legend obverses with Greek reverses. The coins with Latin legends have a portrait of Drusus on the reverse.

\section{Caligula}

A substantial issue of drachms was struck in the name of Caligula (RPC I, 3624). An issue of drachms in the names of Germanicus and Divus Augustus has been assigned either to this reign or that of Tiberius (RPC I, 3623). Analysis might confirm which is correct, but no specimens of these Germanicus drachms were available. 


\section{Claudius}

No coins of the reign of Claudius (RPC I, 3625-30) were available for analysis.

\section{Nero}

The Caesarean silver coinage of Nero can be divided into two groups, on the basis of the portraits and the way Nero's name 'Germanicus' is abbreviated in the obverse legends (RPC I, 556-57). The first of these groups was produced between AD 58 and 60 and has the obverse legend ending in GERMANI (RPC I, 3631-46). No specimens of this group were available for analysis. The second, dated to AD 63-65, has the abbreviation GERM (RPC I, 3647-51) and seems to comprise two separate issues. Five coins of this group were analyzed. Four of these belong to a substantial issue of didrachms and drachms in the name of Nero and Divus Claudius (RPC I, 3647-48). The fifth belongs to the second issue, of drachms and hemidrachms, which bears the types Nero/Mount Argaeus (RPC I, 3649-51). This is the first Caesarean silver coinage to be dated by regnal year, a feature which subsequently became common on the Caesarean silver.

\section{List of Coins of Caesarea, Cappadocia, Sampled Tiberius}

Obv: TIBEPIO $\Sigma$ KAI $\Sigma$ AP $\Sigma$ EBA $\Sigma$ TO $\Sigma$, laureate head right. Rev: $\Theta E O Y \Sigma E B A \Sigma T O Y$ YIO $\Sigma$, Mount Argaeus, surmounted by radiate and naked figure holding globe and sceptre. RPC I, 3620.

Drachm, AD 17-32?

63. Sample A10. Walker 1976, no. 435 (79.5\%).

Obv: TI CAES AVG P M TR P XXXIV or XXXV, laureate head right. Rev: DRVSVS CAES TI AVG F COS (II) TR P IT, bare head of Drusus left. RPC I, 3621-22; RIC I(2), 84-87.

Drachm, AD 33/34.

64. Sample A11. Walker 1976, no. 438 (88\%).

\section{Caligula}

Obv: C CAESAR AVG GERMANICVS, bare head right. Rev: IMPERATOR PONT MAX TR POT, simpulum and lituus. RPC I, 3624; RIC I(2), 63.

Drachm, AD 37/38.

65. Sample A12. Walker 1976, no. 447 (92.5\%).

66. Sample KB4.

\section{Nero}

Obv: NERO CLAVD DIVI CLAVD F CAESAR AVG GERMA, laureate head right. Rev: DIVOS CLAVD AVGVST GERMANIC PATER AVG, laureate head of Claudius right.

$$
\text { AD 63/64? }
$$

67. Sample A13. Didrachm, RPC I, 3647; RIC 620

corr. Walker 1976, no. 479 (82\%).

68. Sample A14. Didrachm, RPC I, 3647; RIC 620 corr. Walker 1976, no. 482 (75\%).

69. Sample E2. Didrachm, RPC I, 3647; RIC 620 corr.

70. Sample A15. Drachm, RPC I, 3648; RIC 622. Obv: NERO CLAVD DIVI CLAVD F CAESAR AVG GERMA, laureate head right. Rev: ET IA, Mount Argaeus surmounted by radiate and naked figure holding globe and sceptre. RPC I, 3650.

Drachm, AD 64/65.

71. Sample A16. Walker 1976, no. 498 (76\%).

\section{Results (Analytical results presented in Table 1) Silver Fineness: Antioch}

Walker (1976) obtained a mean fineness of silver of $72.88 \%$ for the posthumous Philip coinage. His results suggested that this standard continued through the Augustus 'Zeus' issues of Antioch, but that the succeeding 'Tyche' coinage of Augustus was 'markedly higher' in fineness and constituted a 'major reform of the currency' $(1976,68)$. In fact his mean value was only slightly higher than his results for the posthumous Philips, at $78.43 \%$, with individual values varying considerably. For the coinage of Caligula he obtained an average of $67 \cdot 75 \%$, and his variable results for year 3 of Nero indicated another decline in the silver standard. Then came the later coinage of Nero, with a much higher mean value of $79 \cdot 39 \%$, which he compared to the standard used for the Augustan 'Tyche' issues. Finally, the Nero and Divus Claudius issues were considered. Walker rejected any association with Caesarea in Cappadocia (1976, 69), preferring instead a Syrian mint, and found them to be $63 \cdot 46 \%$ fine.

Tabulated, the history of the fineness of the Antiochene coinage according to Walker was as follows:

1. Posthumous Philip coinage: about $73 \%$ fine

2. Augustus 'Zeus' coinage: continuation of the standard used for the Posthumous Philip coinage $(73 \%)$

3. Augustus 'Tyche' coinage: reformed, higher fineness $(78 \cdot 5 \%)$

4. Caligula: much lower fineness $(68 \%)$

5. Nero, year 3: further decline in fineness (58$65 \%)$

6. Nero, years 6/108-116: higher standard, comparable to Augustus 'Tyche' coins (79\%)

7. Nero and Divus Claudius: Lower fineness $(63 \cdot 5 \%)$, comparable to Nero year 3 . 


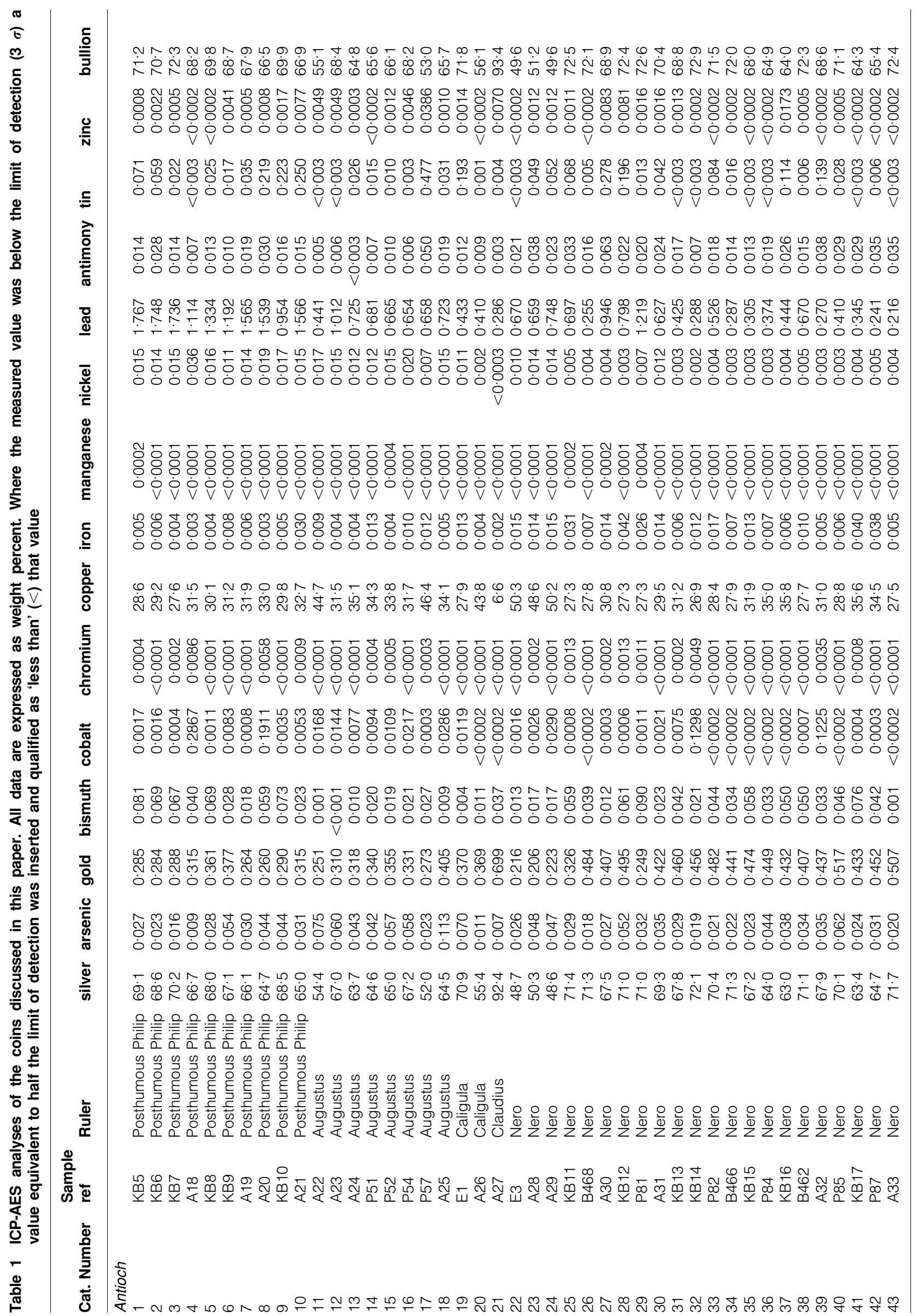




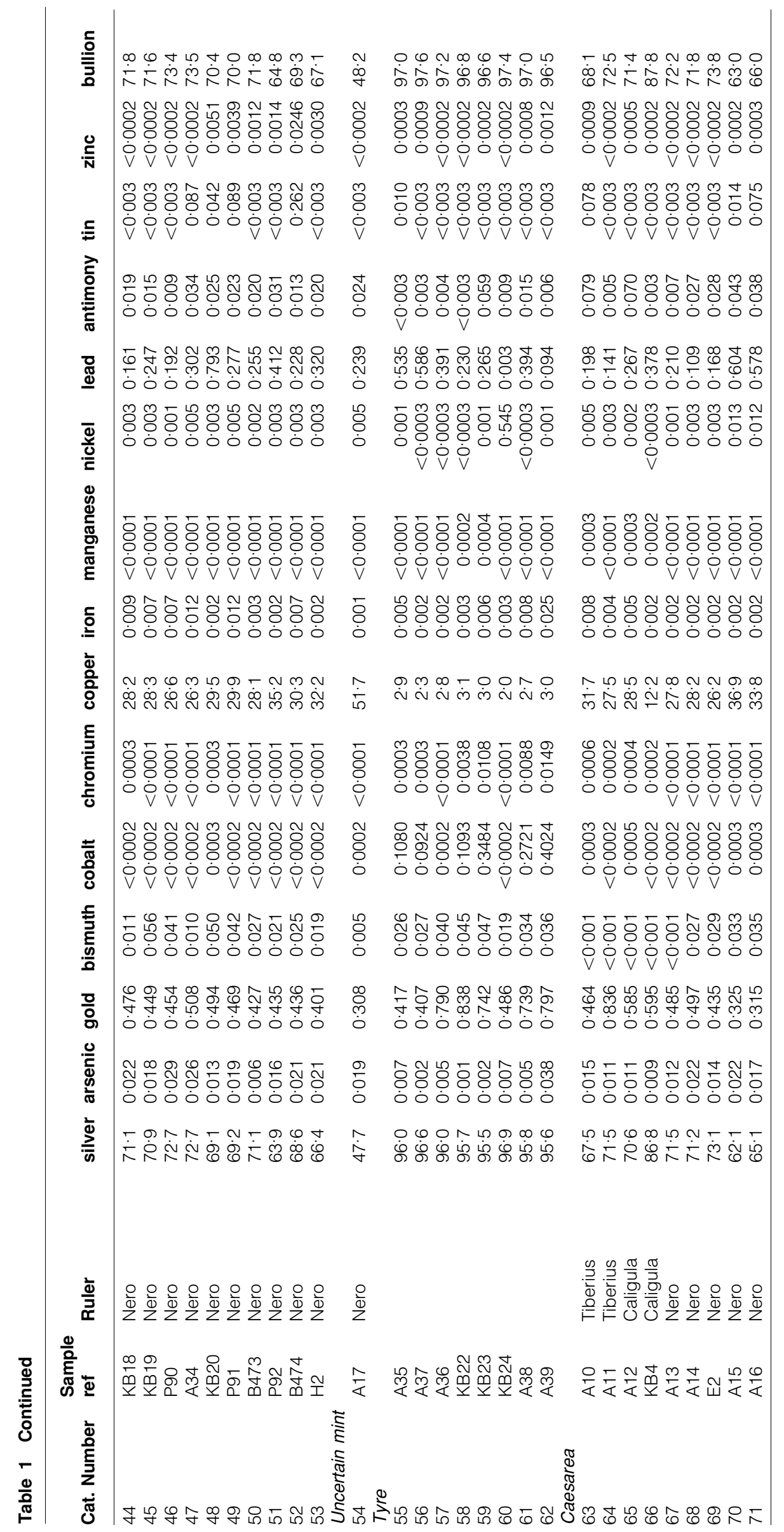


Based on these results, Walker proposed that some tetradrachms were worth three denarii and others four. Support for this can be found in surviving metrological writings, where there are references to an 'Antiochene' standard in which tetradrachms would be the equivalent in value of three denarii; and also to an 'Attic' standard in which tetradrachms would be worth four denarii. With their high silver content, Walker believed that the Tyrian tetradrachms had to be worth four denarii; whereas the baser 'posthumous Philips' were worth three (as were the Augustus 'Zeus' coins of Antioch). Then came a 'major reform': the 'Tyche' tetradrachms of Augustus had a higher silver content, so they too were worth four denarii $(1976,70)$. But the reform was a failure: "Augustus made the mistake of not suppressing the old "autonomous" coinage of Tyre, which, overvalued against the denarius by only $10 \%$, would have been preferred against the new coins of Augustus, overvalued by $25 \% .{ }^{16}$ Thereafter the tetradrachms issued by Caligula, Claudius and Nero were considered three-denarius pieces on account of their lower fineness, until another major reform after year 3 of Nero, when the silver content was raised. In Walker's view it was no coincidence that the new 'eagle' tetradrachms of Nero began to be produced at about the time that Tyrian coinage ended: like the Tyrian coins they were worth four denarii, and they were intended to replace Tyrian silver in circulation. Walker implied that the Neronian 'eagle' tetradrachms succeeded because the Tyrian ones had finally been suppressed. From then on, all tetradrachms were worth four denarii, with the exception of the Nero and Divus Claudius issues (because of their lower silver content these were reckoned to be three-denarius coins).

Walker's results, and his ideas about reforms, have been influential. In very general terms we would not dispute the notion of two different standards for Syrian coins, and indeed these can be considered 'Antiochene' and 'Attic' standards, with tetradrachms equivalent in value to three and four denarii respectively. More will be said about this below.

\section{Posthumous Philips}

Our results for the posthumous coinage in the name of Philip Philadelphus provide us with a mean of $69 \%$ for silver bullion, with very little variation. Walker's

\footnotetext{
${ }^{16}$ As we have seen, the areas of circulation of the Antiochene and Tyrian coins do not appear to have overlapped at this date, so Walker's argument here is somewhat specious. There is certainly no evidence for the presence of 'preferred' Tyrian silver in the north of Syria.
}

mean fineness for elemental silver is not far off this figure $(73 \%)$.

\section{Augustus}

The single Augustus 'Zeus' coin analyzed indicates a much lower standard of fineness (55\% silver bullion). While nothing much can be made of a single result, it is worth noting that this very coin was one of two specimens that Walker also analyzed, where he obtained a mean fineness for elemental silver of 70\% (1976, 60, no. 615).

The 'Tyche' coins, like the Posthumous Philips, are also very consistent, except for one heavily worn specimen with an unusually low fineness of 53\% (P57) which resembles the aforementioned 'Zeus' coin. It is perhaps an irregular or imitative issue, given that the other six range from about 65 to $68 \%$ silver bullion, with a mean value of $66.5 \%$. The fineness of the Augustus 'Tyche' coins would appear to be a little lower than the posthumous Philips (though this difference is almost within analytical error: see $\mathrm{n}$. 18), and not the other way round, as suggested by Walker. Based on these results, it is difficult to support the idea that the Posthumous Philips were worth less than the Augustan 'Tyche' coins. If the earlier Augustan 'Zeus' coins were issued at a lower standard then the introduction of the 'Tyche' issues could still be considered a reform, but all that it achieved in terms of silver content was to restore the coinage to something like the fineness of the posthumous Philips after a brief change of standard for the 'Zeus' coinage (bearing in mind that the evidence for the 'Zeus' coinage standard is based on one result).

\section{Caligula}

Only two specimens were available for analysis, and of these, one had been harshly cleaned, giving a predictably higher reading for silver than the other specimen $(72 \%$ against $56 \%)$. It is clear that more specimens will need to be analyzed before any conclusions can be drawn about this coinage.

\section{Claudius}

The single didrachm of this reign has also been harshly cleaned, and looks as if it may have been firedamaged at some stage in its life. The very high silver content $(93 \%)$ is unlikely to be representative of the true silver content of Claudius' Antiochene issues.

\section{Nero, Year 3}

The three coins analyzed produce very consistent results, with a mean silver bullion content of $50 \%$. 


\section{Nero, Years 6/108-16}

There are sufficient specimens of Nero's later coinage to make a study of the fineness by year. The results are as follows:

6/108: $72 \cdot 4 \%$
7/109: $71 \cdot 3 \%$
8/110: $71 \cdot 1 \%$
Mean for $6 / 108-8 / 111: 71 \cdot 4 \%$
9/111: $68 \cdot 1 \%$
10/111: $64 \cdot 8 \%$
10/112: $72 \cdot 3 \%$
Mean for $9 / 111-10 / 112: 68 \cdot 3 \%$
114: $71 \cdot 4 \%$
116: $67 \%$

Some very minor variations can be observed from year to year (the lowest being for the two specimens of year 10/111), or between different groups, but as a whole this coinage exhibits a remarkable consistency. The overall mean silver bullion fineness for Nero's 'eagle' tetradrachm coinage at Antioch is $70 \%$, which is essentially (within analytical error) ${ }^{17}$ the same fineness used for the coinage of Philip Philadelphus $(69 \%)$. The two can be regarded as equivalent. The same may be said, with only slight reservations, about the Augustan 'Tyche' coinage: it is essentially (again within analytical error) the same fineness as the other two coinages $(67 \%)$.

The other coinages are more difficult to interpret because of the small numbers of specimens available for analysis. The coins of Nero's year 3 are the most consistent, at 50\% fine. The Caligula and Augustan 'Zeus' coins may be of a similar standard, but more analyses are needed.

Tabulated, the history of the fineness of the Antiochene coinage according to our results is as follows:

1. Posthumous Philip coinage: $69 \%$ fine

2. Augustus 'Zeus' coinage: $50 \%$ ?

3. Augustus 'Tyche' coinage: $67 \%$

4. Caligula: $50 \%$ ?

5. Claudius: ?

6. Nero, year 3: $50 \%$

7. Nero, years 6/108-116: $70 \%$

\footnotetext{
${ }^{17}$ All instrumental analyses are subject to errors caused by various unavoidable factors. These should be quantified through the use of certified standard reference materials or similarly reliable standards. For the analyses of the major alloying components reported here (silver and copper) the error is generally in the order of $\pm 1-2 \%$; it can therefore be stated that a reported value of $69 \%$ has an error of up to $2 \%$ either side $67 \%$ to $71 \%$. Consequently any discussion of instrumental data that places any interpretative significance on differences of less than the stated analytical error is entirely specious.
}

\section{The Silver Fineness of the Nero and Divus Claudius Tetradrachms}

The single coin of this issue that was analyzed has a silver bullion content of $48 \%$. Not much can be said based on a sample of one, but the fineness looks as if it is the same as that employed for year three of Nero (i.e. about $50 \%$ ).

\section{Tyre}

A single fineness was employed at Tyre throughout. The coinage was very fine, although it was not pure silver bullion. Instead it was about $97 \%$ fine, with some $3 \%$ copper deliberately added. The weight of a Tyrian tetradrachm was about $14 \cdot 1 \mathrm{~g}$ (Butcher and Ponting 2005b, 112), and contained about $13.7 \mathrm{~g}$ of silver.

\section{Caesarea in Cappadocia}

The alloy is clearly not the one used at Caesarea in Cappadocia from Vespasian onwards (Butcher and Ponting 1995; 1997; Gitler and Ponting 2003), which was about $50 \%$ fine. Instead it appears to be the same as the alloy used for the Syrian Posthumous Philips, Augustus 'Tyche' tetradrachms and Nero 'eagle' tetradrachms.

Walker $(1976,43)$ proposed that the Greek legend drachms of Tiberius were struck at a lower fineness than his Latin ones; our sample (one of each) is too small to determine whether this was indeed the case (the Greek legend drachm has a slightly lower fineness of $68 \cdot 1 \%$ against the Latin drachm's $72.5 \%$ but this may be largely due to analytical and sampling error).

Two drachms of Caligula were analyzed. One was clearly fire-damaged and had been harshly cleaned; not surprisingly it had a high silver content of $87 \cdot 8 \%$. The other is much more consistent with the Tiberian drachms, at $71 \cdot 4 \%$.

Walker also thought he could detect a decline in fineness towards the end of Nero's reign, in the Nero and Divus Claudius coinage, and the Neronian Mount Argaeus issues. The results for the didrachms (72.6\% fine) do not support this, but the single specimens of drachms for Nero and Divus Claudius and Mount Argaeus are slightly lower (63\% and 66\% respectively), although it would be useful to analyze more specimens before drawing any conclusions. Overall, however, the Neronian coins appear to be on the same standard as those of Tiberius and Caligula, and, as stated above, this alloy is the same as that used for the Antiochene posthumous Philips, the Augustan 'Tyche' tetradrachms and the Neronian 'eagle' tetradrachms. 


\section{'Antiochene' and 'Attic' Standards?}

A pattern seems to be emerging for the finenesses. At $97 \%$ fine the Tyrian silver is unique among the coinages examined here. Of the other coins, most fall into two groups: one at approximately $70 \%$ fine, the other at about $50 \%$ fine. Those coins that do not fit with this model appear to have suffered depletion of copper as a result of fire damage and/or harsh chemical cleaning.

Whether these standards are creations of the Roman period, or were invented earlier, cannot be explored here because no relevant Hellenistic coins have been analyzed. However, in a previous paper we described our results for some drachms of the kingdom of Cappadocia, struck in the 1st century BC (Butcher and Ponting 1997, 170). These were issued on the $50 \%$ standard, so at least one of our standards has a history that predates Roman control. We regard it as quite likely that both of these standards were in use before the Roman annexation of Syria, but this has yet to be demonstrated. ${ }^{18}$

Expressed as ratios or fractions, one alloy (70\%) seems to be composed of approximately one part copper to two parts silver $(1 / 3$ to $2 / 3)$. The other is one part copper to one part silver $(1 / 2$ and $1 / 2)$. If the former is to be regarded as the 'Attic' standard, with a tetradrachm worth four denarii, then the other fineness stands in the correct relationship to it if it is to be regarded as the 'Antiochene', with a tetradrachm worth three denarii (three-quarters of twothirds equals a half). ${ }^{19}$ But perhaps it would be wisest not to insist on a correlation between these names and the alloys at this point.

Whatever we might call them, the two standards would appear to have been employed as follows:

1. Posthumous Philip coinage: $69 \%$ fine = 'Attic'?

2. Augustus 'Zeus' coinage: $50 \%$ ? ='Antiochene'?

3. Augustus 'Tyche' coinage: $67 \%=$ 'Attic'?

4. Caligula: $50 \% ?=$ 'Antiochene'?

5. Claudius: ?

6. Nero, year 3: 50\%='Antiochene'?

7. Nero 'eagle' coins, years 6/108-116: 70\%= 'Attic'?

8. Nero and Divus Claudius: 50\%?='Antiochene'?

\footnotetext{
${ }^{18}$ Given the extreme reluctance on the part of curators of major collections to allow access for sampling, the history of silver standards in late Hellenistic times is unlikely to be explored any time soon.

${ }^{19}$ This definition of 'Attic' or 'Antiochene' standards, which takes into account the type of alloy in addition to weight, would appear to be significantly different from the definition employed by scholars of Greek numismatics, who tend to define 'Attic' by weight alone (since the finenesses of Greek coins are not generally known).
}

It should be noted that our analyses of some later Syrian tetradrachm coinages show these standards continuing to be employed: in the early years of Trajan's reign tetradrachms were struck at about $67 \%$ fine, whereas those issued later in the reign were $50 \%$ fine (Butcher and Ponting 1998). This switching back and forth from two different standards is very difficult to reconcile with the general notion of a slow decline in standards over time. It may be the case that coins on the two standards had the same face value, making the $50 \%$ standard overvalued against the $67 \%$ by a third. To the naked eye the differences in fineness would have been invisible. On the other hand, if the $50 \%$ coins were overvalued, presumably they were an attempt to deceive the public; and if that were the case, why did the issuing authorities persist in making coins at the higher standard when they could get away with the lower one? Do reversions to a higher fineness indicate that the deception was unsuccessful? Why were other finenesses not tried? Alternatively, one might propose that the different standards did indeed mean different face values, and that some tetradrachms were worth three quarters the value of the others. The issues could certainly be distinguished by their types. As we have noted, hoarding patterns seem to suggest that a distinction was made: Posthumous Philips were hoarded with Augustus Tyche coins, and Neronian 'eagle' tetradrachms with issues of later emperors, with the issues at the 50\% standard apparently absent from both. This does suggest that people did acknowledge that there were differences; it would be useful to have more hoard evidence to help determine whether the distinctions were made because of overvaluation, face values, differences in type, separate pools of circulation, or combinations of these factors.

These two standards can also be found in use elsewhere. At Caesarea the $70 \%$ fineness was employed under the Julio-Claudians, but, as we have noted above, from Vespasian onwards the 50\% fineness was employed (Butcher 1992, Butcher and Ponting 1995, 1997). If Julio-Claudian coins of Caesarea continued to circulate at the same face value as the later issues, the latter would have been overvalued by $33 \%$. The (admittedly meagre) hoard evidence suggests that the two did not circulate together to any great extent.

The Tyrian standard is, of course, different, and it would be impossible to reconcile the $97 \%$ and $70 \%$ finenesses as a single 'Attic' standard, even taking into consideration the higher average weight of the Antiochene tetradrachms versus the Tyrian. 
However, as we have argued elsewhere (Butcher 2004; Butcher and Ponting 2005b), the separate patterns of production and circulation of Tyrian and Antiochene coins mean that the two standards did not necessarily have to relate to one another for the purpose of everyday exchange, because the coins did not circulate alongside one another. The Tyrian silver standard seems to be linked to a different set of standards used in Egypt and its demise under the Julio-Claudian emperors (together with a concurrent debasement of Egyptian silver) may well be because of a process of rationalization of silver standards that took place under Nero (Butcher and Ponting 2005b). It is significant that when the Tyrian coinage came to an end and the Neronian 'eagle' tetradrachms came to dominate circulation in Syria, the fineness of Egyptian silver was adjusted to relate to the Antiochene tetradrachms of Nero instead of the Tyrian coinage to which it had previously related (Butcher and Ponting 2005b).

For reasons of length a more detailed study of the relationship of the various coinages to one another, and to the Roman denarius, cannot be provided here; this will have to be reserved for a later synthesis. It is now time to turn from silver content to the results for trace and minor elements.

\section{Trace elements and the pattern of production at Antioch}

The chemical analysis measured twelve minor and trace elements in addition to the silver and copper that forms the basis of the preceding discussion. These elements are contaminants that relate to the origin of the silver and/or copper in the alloy, the smelting processes used to extract these and the refining processes used when recycling the coins. On the basis of the geo-chemistry of the ores most likely to have been exploited for silver and copper extraction, and the current levels of understanding of the smelting and refining processes used in antiquity, the suite of minor and trace elements can be divided into two; those most likely to be associated with the silver and those most likely to be associated with the copper, although the distinction is not always clear or reliable.

Most silver ores will also contain traces of gold and bismuth that will not be removed during traditional smelting and refining processes (Craddock 1995, 21114). Additionally, lead ores were commonly exploited for the silver they contained and so consequently lead is also usually found in ancient silver. However, lead would also have been added during the refining and recycling of silver-alloys in order to concentrate the silver (ibid.). Lead therefore could have come into the silver by two independent avenues; the original ore and subsequent refining. These three trace elements can also occur in traditionally smelted copper, but normally at considerably lower concentrations; these are usually below the detection limits of the technique used here.

Copper ores are very varied and can contain a large number of associated minerals at various concentrations. In general it is known that arsenic, antimony, iron, nickel, cobalt, chromium, tin, zinc and manganese can all be found in traditionally smelted copper at various concentrations, as well as minute traces of gold, bismuth and lead. Cobalt and chromium can also be found in some scarce silver ores. However the concentrations of all of these elements in the smelted copper will bear little or no relation to the concentrations in the original ore. This is because of the changes caused by the smelting and subsequent refining processes (Tylecote et al. 1977; Craddock and Giumlia-Mair 1988). However, the trace elements in copper do represent the cumulative effect of ore source, smelting process and refining/recycling strategy. The combined effect of these processes can sometimes mean that the trace element concentrations of copper smelted and refined under a specific combination of conditions at a particular place and at a particular time, may well have a very particular combination of trace element concentrations; almost certainly not unique, but occurring rarely enough for them to be useful in characterizing copper-alloys.

Examination of the concentrations of the trace elements that are mainly associated with the silver in the alloy of the Antiochene coins reveals some interesting structure (Fig. 1).

There is a series of clear groupings on the basis of the gold and lead concentrations that appears to be related to chronology. There is a general trend of increasing gold and declining lead content during our period that suggests a continual supply of silver that gradually changed its supply source/s with a more significant shift during the early years of Nero's reign. A similar chronological trend has been recognized in the contemporary denarii, although one that sees a gradual decline in the gold concentration (Butcher and Ponting 2005a). The majority of the issues of Nero form a tight group defined by high concentrations of gold and relatively low concentrations of lead; most of the coins in this group were issued in the 8th, 9th and 10th years of his reign. This grouping starts the year before the change in reverse type from left facing eagle to right facing eagle (beginning with year 9). Most of the earlier issues (years 3, 6 and 7) do not fit into this group. These earlier coins, however, 


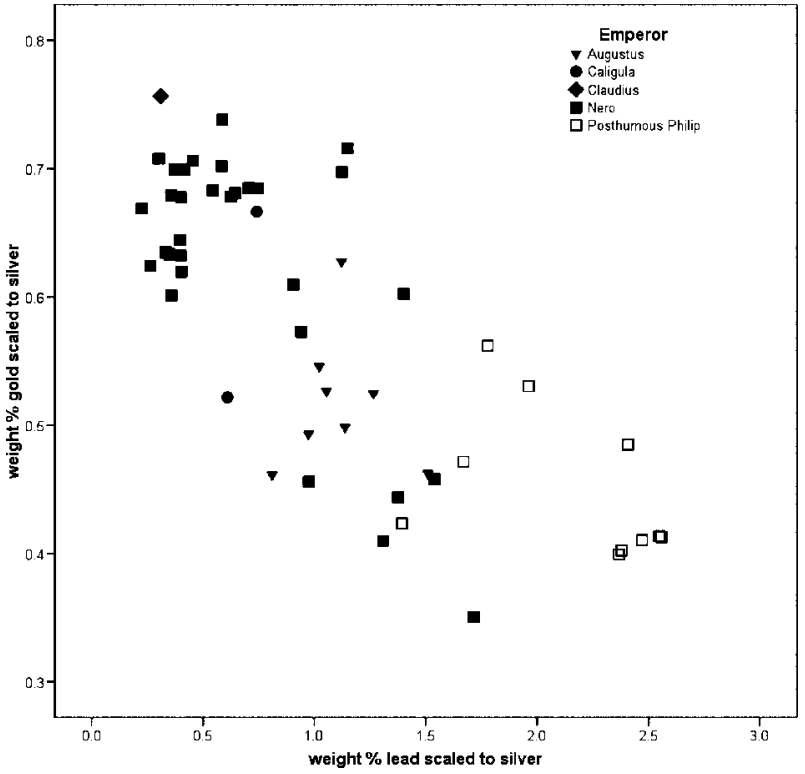

Figure 1 Scatterplot of the lead and gold contents (scaled to the silver) of the Antiochene coins

overlap with the issues of Augustus, Caligula and particularly the posthumous issues of Philip Philadelphus. Furthermore, the overlap between the posthumous Philip coins and the earlier issues of Nero may indicate that the posthumous Philips (and perhaps the Augustan coinages) were recycled into Nero's coinages of years 3, 6 and 7 .

The traces associated with the copper also support the idea of a shift in metal supply throughout our period. The cobalt and nickel concentrations (Fig. 2) arrange the posthumous Philip coins and those of Augustus in two overlapping groups that are quite

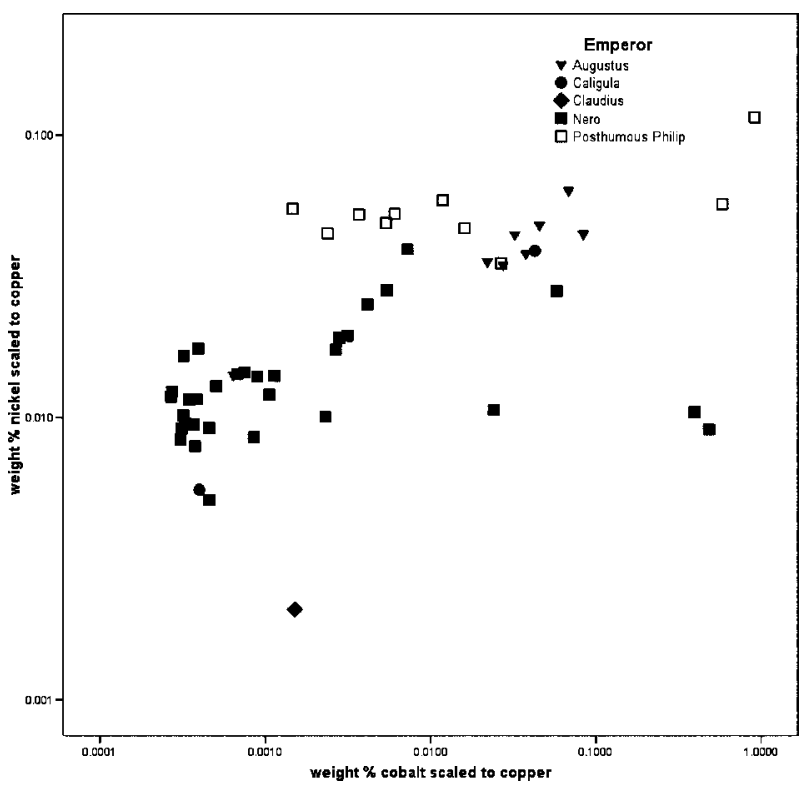

Figure 2 Scatterplot of the cobalt and nickel contents (scaled to the copper) in the Antiochene coins

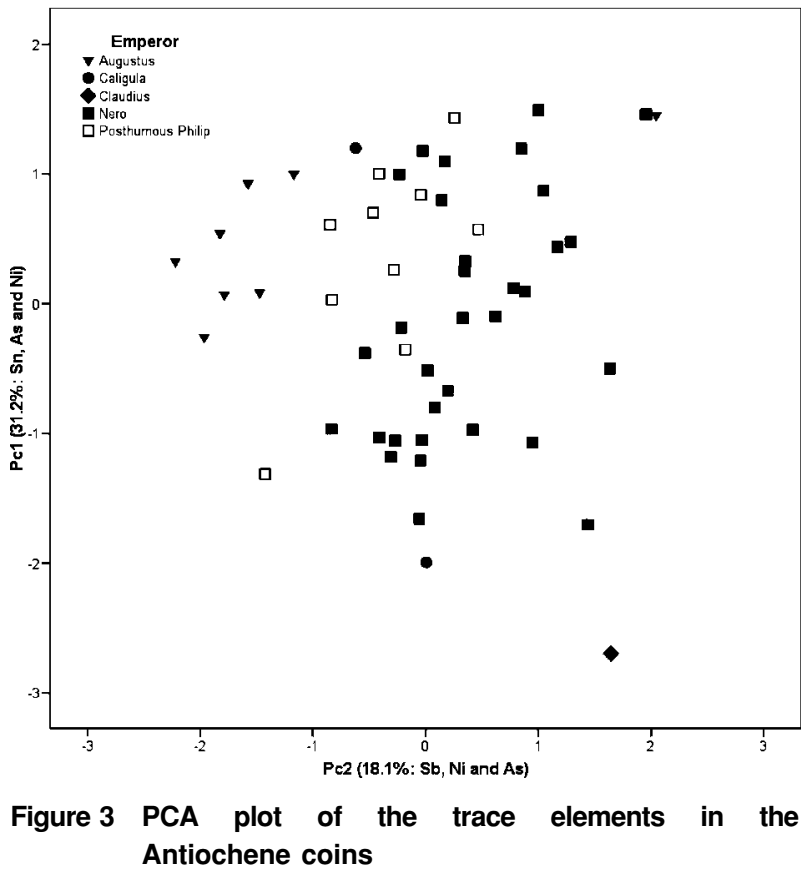

different to the issues of Nero. One of the two coins of Caligula sits with the issues of Augustus whilst the other sits with those of Nero. The single coin of Claudius sits with those of Nero. Similar groupings are obtained for the other trace elements as can be seen in the principal components plot ${ }^{20}$ (Fig. 3).

It can therefore be suggested that the posthumous Philip coins and those of Augustus were produced from copper with a similar trace finger-print; possibly the same or closely related sources. Clearly there is a significant change in copper source between Augustus and Nero, although when this occurred is not clear. The three relevant coins could indicate a date in Caligula's reign, although more analyses would be needed to establish the veracity of this suggestion one way or the other.

\section{Trace elements and the pattern of production at Tyre}

Comparison of the trace elements of the Tyrian coins with those of the Antiochene issues show some curious trends. Generally speaking, the metal used for these two coinages is quite different. However this does not mean that there is necessarily no relationship between the two. A basic exploratory PCA of the logged trace elements (Fig. 4) demonstrates the basic and unequivocal compositional difference, most marked along the axis defined by the arsenic, gold and tin contents. However, if those elements most

${ }^{20}$ Principal components analysis (PCA) is a statistical technique used to simultaneously explore data consisting of several variables. This is done by creating a linear combination of the variables that retains the combined structure of all the original variables together in only two or three variables. 


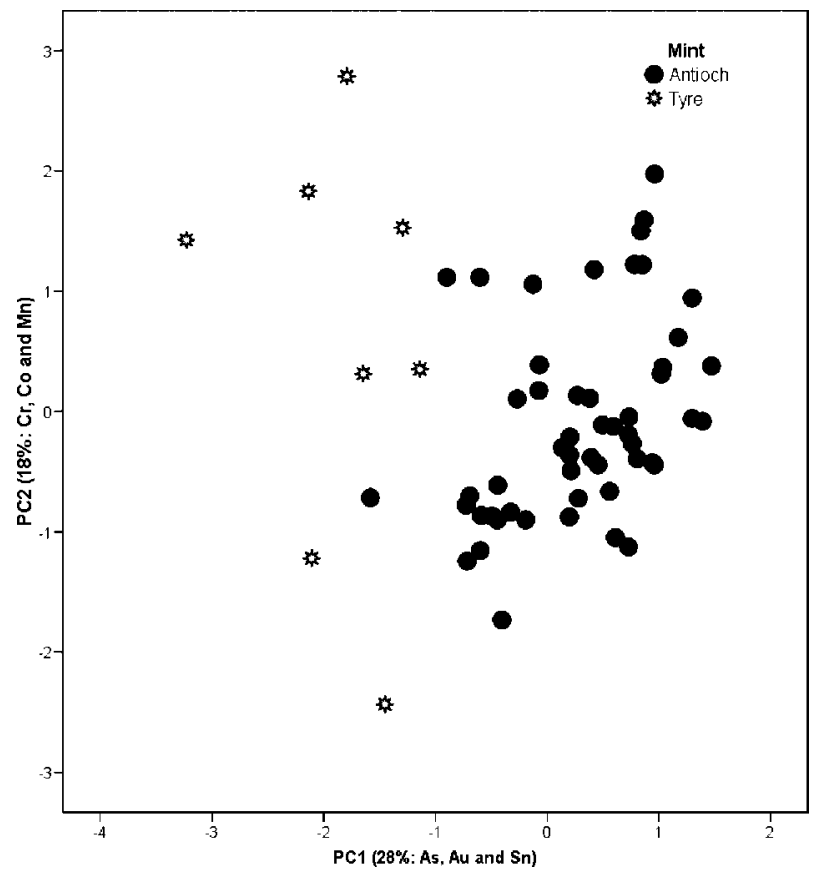

Figure 4 PCA plot of the trace elements in the Antiochene and Tyrian coins

likely to be related to the silver bullion used in the manufacture of these coins (gold and bismuth) are plotted there is little obvious difference (Fig. 5).

Nevertheless, closer scrutiny reveals that the Tyrian coins form two groups; one defined by high levels of gold, the other by low levels of gold. However, these groups are not defined by issue date or any other apparent criteria. Between these two groups are the Antiochene coins, with the later issues of Nero forming a cluster almost equidistant between

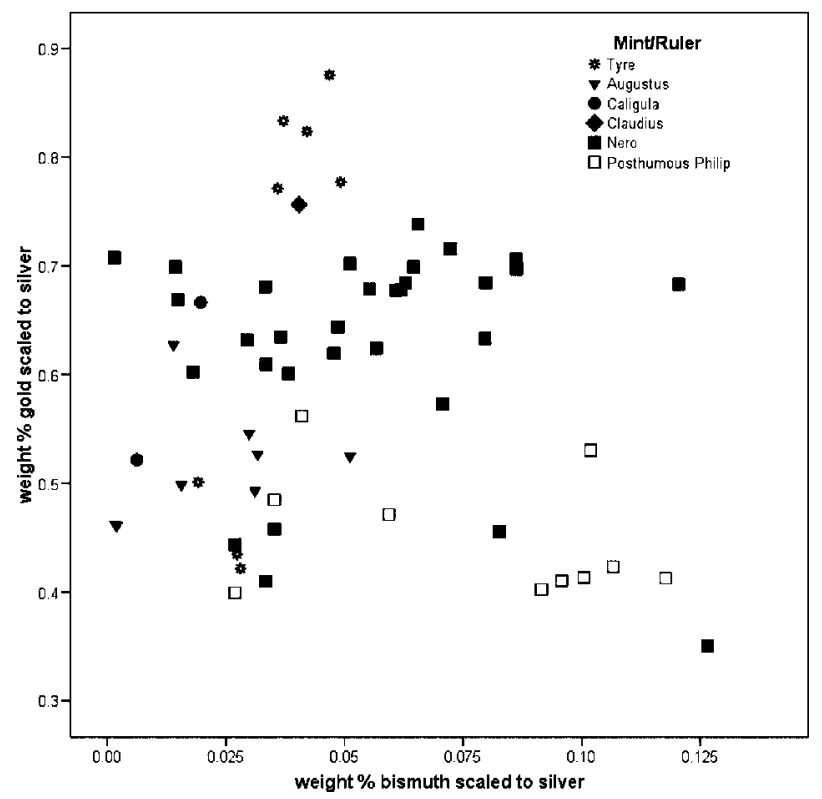

Figure 5 Scatterplot of gold and bismuth contents (scaled to the silver) in the Tyrian and Antiochene coins

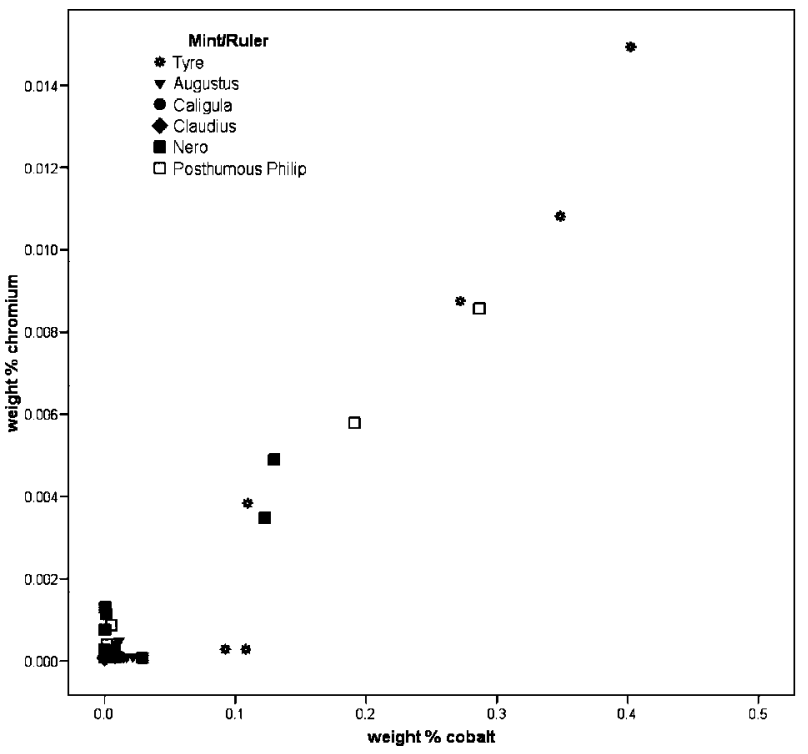

Figure 6 Scatterplot of cobalt and chromium contents (unscaled) in the Tyrian and Antiochene coins

the two groups of Tyrian coins; such a position could be the result of mixing the silver of the two Tyrian groups together, thereby forming a mixing line between the two original (Tyrian) groups along which the Neronian coins cluster. The recycling of Tyrian coins following their discontinuation is highly likely; as noted at the beginning of this paper, they had disappeared completely in hoards by the 2nd century AD.

Turning to the other trace elements, it is apparent that there are some extremely high levels of cobalt, nickel and chromium that characterize the Tyrian coins and mark them out as different from the Antiochene issues. These elements are usually associated with the copper portion of a silver alloy; however, if all the cobalt originated solely in the copper portion of the alloy then the cobalt content of this metal would have been anything up to $13 \%$, and one coin (KB24) would have been made from copper containing 27\% nickel. These figures are highly unlikely and in this case must therefore indicate that most of the measured cobalt, chromium and nickel originated with the silver (approximately $0 \cdot 4 \%$ cobalt scaled to silver). This view is supported by the fact that most of the coins containing high levels of cobalt also contain high levels of gold and bismuth. The cobalt and chromium are also highly correlated in half of the cases, confirming the geo-chemical association between the two elements (Fig. 6).

Silver sources that contain high levels of cobalt fall into two categories; nickel-cobalt-native silver and cobalt-type dry ores such as silver sulphide (or sulpharsenide) (Bastin 1939; Dayton 1993). The high 


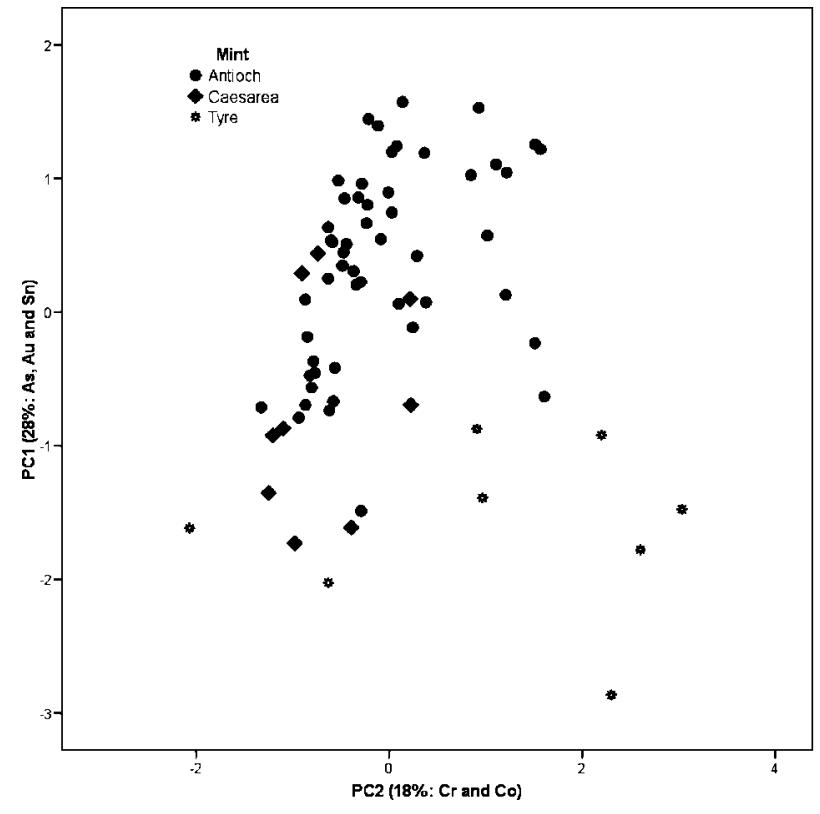

Figure 7 PCA plot comparing the issues of Antioch, Caesarea and Tyre

levels of gold and bismuth also associated with most of the Tyrian coins may also point to a dry-ore or native silver origin (Craddock 1995). The sources of such ore types are rare and according to the modern geological literature do not occur in the Near East. In fact there are only three possible contenders in Europe and the Mediterranean region, these are the Erzgebirge region of Germany (Saxony), a small deposit in Alsace and a third in southern Sardinia (Bastin 1939; Dayton 1993). However, the two Tyrian coins subjected to lead isotope analysis (KB23 and A36; Fig. 9) have a clear Anatolian (Taurus mountain) signature, although only one of these (A36) has high cobalt and chromium levels. The possibility of nickel-cobalt-native silver occurring in Anatolian silver deposits long since worked-out is, however, conceivable. Bastin (1939) states that nickel-cobaltnative silver and cobalt-type dry ores occur in bodies characterized by specific minerals: arsenides and antimonides together with galena and chalcopyrite. Such mineralization does occur in the Taurus mountains, notably around Gumuşane and possibly Bulgar Maden, although information is hard to find (DeJesus 1980). The available evidence therefore suggests that a significant proportion of Tyrian silver coins were produced from old silver bullion from ancient native nickel-cobalt-native silver/cobalt-type dry ore sources in Anatolia that are no longer in existence (or have yet to be identified). It should also be noted that a small number of the Antiochene coins also have high cobalt and chromium levels, and would therefore seem to confirm the likelihood that

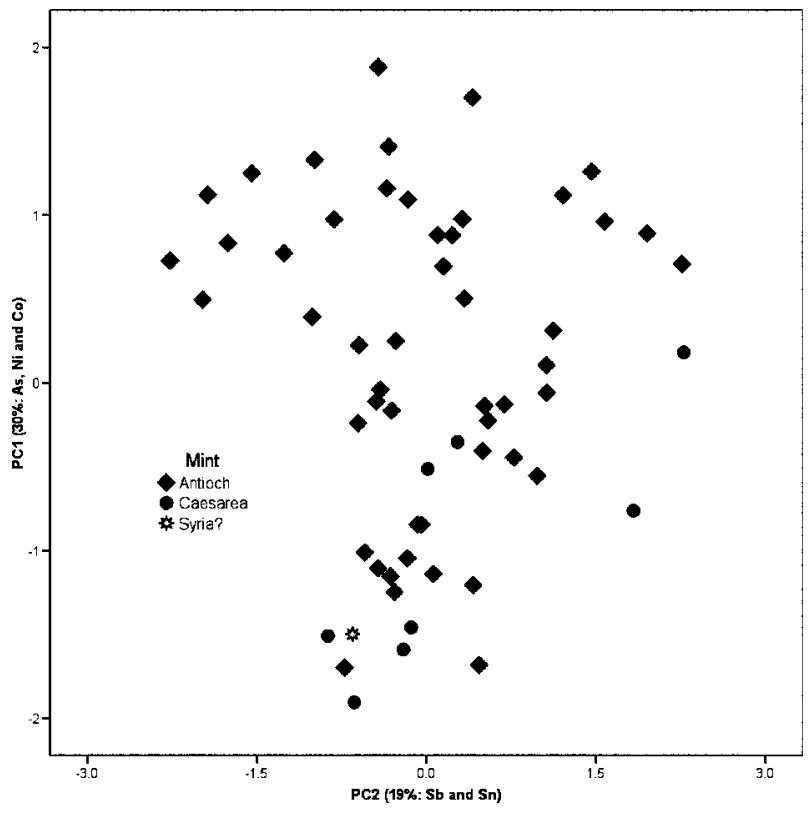

Figure 8 PCA plot of the trace element data for the issues of Caesarea and Antioch including the Nero and Divus Claudius tetradrachm attributed to Syria

some Tyrian coins were recycled into Antiochene tetradrachms.

Trace elements and the pattern of production at Caesarea

A PCA analysis of the trace elements across all the issues of Tyre, Caesarea and Antioch suggests strong similarities between the metal used for both the Caesarean issues and the Antiochene issues (Fig. 7).

The coins of Tyre continue to remain compositionally different, primarily due to the unusual levels of cobalt and chromium. There is some evidence of compositional differences between Caesarea and Antioch, however, with the majority of the Caesarean coins clustering at the southernmost point of the Antiochene group. If a PCA analysis is re-run after excluding the Tyrian coins, the separation between the Caesarean issues and those of Antioch becomes more apparent (Fig. 8) and all these suggestions are further reinforced by the lead isotope analysis reported in the next section (Fig. 9).

\section{Trace elements and the Nero and Divus Claudius Tetradrachms}

The origin of the Nero and Divus Claudius tetradrachms has now been resolved by analysis. Obviously it would be desirable to analyze more of these coins to see if the results can be replicated, but the combination of trace element data (Fig. 8) and lead isotope values confirms what others have observed regarding the style of these coins. The plot 


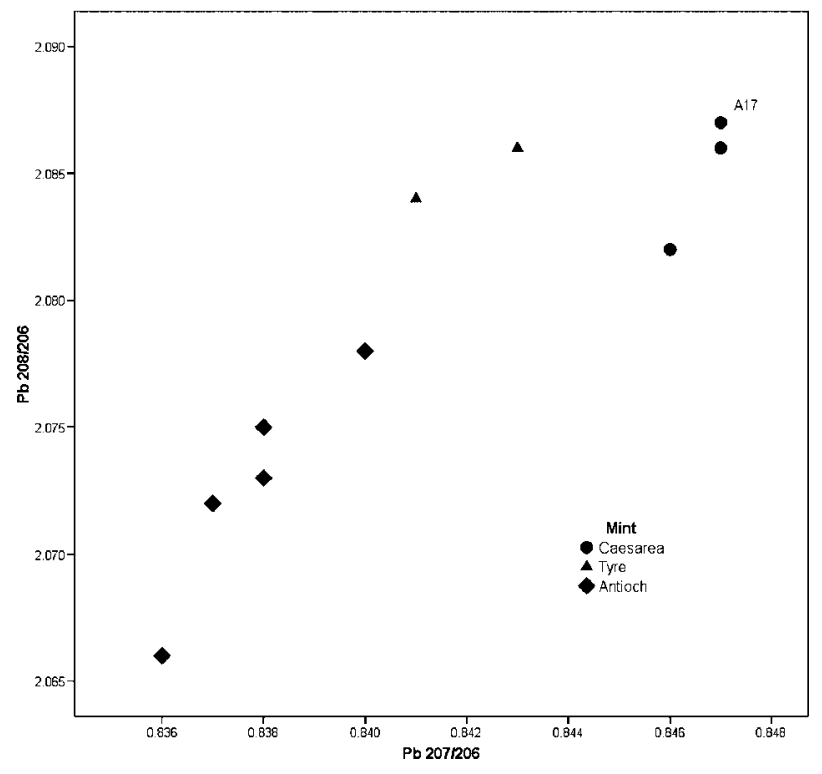

Figure 9 Plot of lead isotopes of Caesarean, Tyrian and Antiochene coins

of the lead isotope data ${ }^{21}$ (Fig. 9) clearly shows the Nero and Divus Claudius tetradrachm (A17) sitting with the other two coins issued by Caesarea (both of these are Nero and Divus Claudius didrachms, samples A13 and E2); furthermore, this group is well separated from both the Antioch issues and the Tyrian coins. It therefore seems that the tetradrachm was produced from the same silver bullion stock as the didrachms, and that Caesarea in Cappadocia was the place of minting.

The date of the didrachms and tetradrachms is likely to be more or less the same. In RPC I (p. 557) there is a tentative argument for a date for the didrachms of $c$. AD 63/64-64/65 (the same time that the dated drachms and didrachms with the Mount Argaeus reverse were produced), but the tetradrachms are assigned a broader chronology of $c$. AD 63-68 (RPC I, 605). Walker dated them to AD 62/63 in connection with the Parthian crisis $(1976,69)$, but the portraits of Nero on them indicate a date of 63 at the earliest (RPC I, 557, 605). Given that there is a range of styles of portraits found on both didrachms and tetradrachms, it might be better to see both series of coins being produced over several years, and simply to date them all broadly to 63-68.

It would be desirable to subject more specimens of both the Nero and Divus Claudius tetradrachms and the didrachms and drachms to the same type of analysis, but the results given thus far support a connection between all three denominations.

\footnotetext{
${ }^{21}$ Only a representative selection of coin samples could be subjected to lead isotope analysis.
}

However, it is still unclear whether the tetradrachms were made for circulation in the areas where Caesarean coins normally circulated or whether they were produced there and then sent to Syria. The very meagre evidence from find spots suggests that the latter is more likely (Butcher 2004, 68-69; see also above); note also that they are separated from the didrachms and drachms by their alloy: the tetradrachms appear to have been issued on the lower fineness $(50 \%)$ rather than the $67-70 \%$ of contemporary Caesarean coinage.

\section{Conclusions}

During the period covered by these analyses there was no significant decline in the fineness of Antiochene tetradrachms, although alternating finenesses of about $67 \%$ and $50 \%$ silver were employed for different issues. It would be helpful to have reliable information about where the 50\% silver coinages circulated, and in what ways they might have related to the $67 \%$ ones. The issues at $50 \%$ may represent occasional attempts to introduce overvalued coins into circulation alongside those at the $67 \%$ fineness, but hoard evidence suggests that the public was able to distinguish between them and it is quite unclear whether they regularly circulated together. An alternative suggestion is that the finenesses reflect the existence of two different standards and that, instead of being overvalued, the $50 \%$ silver coins circulated at three-quarters the value of the finer coins. Such a relationship has the support of ancient authorities, though it will undoubtedly seem controversial for many numismatists working on provincial coinages.

During this period, the extremely fine (but not pure) silver coinage of Tyre was discontinued, and the end of Tyrian coinage coincides more or less with the introduction of the Antiochene 'eagle' tetradrachms of Nero to the region where Tyrian coins circulated. Incompatibility of silver standards may in part explain Tyrian silver's demise; as we have indicated elsewhere (Butcher and Ponting 2005b) its extinction may also be connected with the debasement of the denarius under Nero in AD 64, which left Tyrian denominations undervalued against all other silver currency being issued in the Roman world. Trace element analysis suggests that some of the Tyrian silver of this period might have been recycled as Neronian 'eagle' tetradrachms of Antioch, and we might expect tetradrachms of Nero's successors to exhibit similar evidence for recycling.

The Julio-Claudian coinage of Caesarea in Cappadocia was issued on the same $67-70 \%$ standard 
as the Antiochene coinage. It therefore seems likely that the Caesarean drachm was worth a quarter of the Neronian 'eagle' tetradrachms of Antioch. Parity between Antioch and Caesarea was not necessary for ensuring their compatibility in local markets because there is no certain evidence that the products of the two mints circulated together. Instead it suggests that the common standard was influenced by other considerations, such as adherence to generallyaccepted bench marks for the fineness of silver coinage. The subsequent issues of Caesarea under the Flavians and their successors were struck on the lower, $50 \%$ fineness, a standard which, as we have seen, was also in use in Syria.

The trace elements show some affinities between Antioch and Caesarea, but with enough differences to distinguish them. Significantly, the trace elements and lead isotopes allow us to place the enigmatic Latin legend tetradrachms of Nero and Divus Claudius with stylistically and typologically similar issues of didrachms and drachms assigned to Caesarea. From the point of view of production, at least, the tetradrachms would appear to form part of the same issues as the smaller denominations. Their fineness, however, suggests that for the purposes of circulation they were not meant to circulate with the Caesarean coins.

The trace elements have also hinted at possible sources of raw materials and patterns of recycling which tend to support observations about circulation patterns derived from hoards. Tyrian coinage may have utilized old silver bullion (or older coins) with trace element profiles that were no longer particularly characteristic of other Roman period bullion sources for coinage. This material, with its unusual trace element signature, did not find its way into other Julio-Claudian tetradrachms issued prior to Nero's 'eagle' coinage, perhaps because the pools of circulation and systems for withdrawal and recycling of Antiochene and Tyrian tetradrachms were normally kept separate up to this date. Indeed, the earliest Neronian tetradrachms show signs of having been produced from posthumous Philip and Augustan tetradrachms; only with the end of the Tyrian coinage, the introduction of the Neronian 'eagle' tetradrachms and the spread of the latter into areas formerly dominated by Tyre, did the recoining of Tyrian into Antiochene silver begin.

\section{Acknowledgements}

This work forms part of a project funded by the Leverhulme Trust (MP) (No. RF\&G/6/2002/0336) and the Faculty of Arts and Science Research
Committee and the University Research Board of the American University of Beirut (KB). The authors would like to thank Professor C. J. Howgego and the Visitors of the Ashmolean Museum, Oxford, for kind permission to sample Syrian and Cappadocian coins in the collection housed in the Heberden Coin Room; and to three private collectors (Michel Prieur, Paris; Bruno van der Pluijm, New York; and a third collector in the UK who wishes to remain anonymous) for their scholarly spirit and generosity in providing coins from their respective collections for analysis. Access to ICP-AES instrumentation was kindly provided by Chris Somerfield of The School of Environmental and Chemical Engineering at Nottingham University, the Lead Isotope determinations were conducted by the NERC Isotope Geochemistry Laboratory (NIGL), Keyworth, Nottinghamshire, under the watchful eyes of Dr Jane Evans and Vanessa Pashley.

\section{Bibliography}

Abramzon, M. G. (2003) The Gerzeul hoard of coins of Caesarea in Cappadocia. Revue Numismatique 159, 243-56.

Baldwin, A. (1927) Un trésor monétaire découvert à Césarée. Aréthuse 4, 145.

Bastin, E. S. (1939) The nickel-cobalt-native silver ore type. Economic Geology 34/1, 1-40.

Butcher, K. (1992) Rhodian drachms at Caesarea in Cappadocia. Numismatic Chronicle 152, 41-48.

- (1996) Coinage and currency in Syria and Palestine to the reign of Gallienus. Pp. 101-12 in C. E. King and D. G. Wigg (eds), Coin Finds and Coin Use in the Roman World. The Thirteenth Oxford Symposium on Coinage and Monetary History, 25.-27.3.1993. Berlin: Gebr. Mann Verlag.

- (2004) Coinage in Roman Syria. Northern Syria, 64 BC-AD 253. London: Royal Numismatic Society Special Publication 34.

- and Ponting, M. (1995) Rome and the East: Production of Roman provincial silver coinage for Caesarea in Cappadocia under Vespasian, AD 69-79. Oxford Journal of Archaeology 14, 63-78.

- (1997) Silver standards at Caesarea in Cappadocia. Pp. 167-71 in J. Nollé, B. Overbeck and P. Weiss (eds), Internationales Kolloquium zur kaiserzeitlichen Münzprägung Kleinasiens. 27.-30. April 1994 in der Staatlichen Münzsammlung, München. Nomismata, Historische-numismatische Forschungen 1. Milan: Edizione Enerre.

- (1998) Atomic absorption spectrometry and Roman silver coins. Pp. 308-34 in A. Oddy and M. Cowell (eds), Metallurgy in Numismatics 4. London: Royal Numismatic Society Special Publication 30.

- (2005a) The Roman denarius under the Julio-Claudian emperors: mints, metallurgy and technology. Oxford Journal of Archaeology 24/2, 163-97.

- (2005b) The Egyptian Billon tetradrachm under the Julio-Claudian emperors - fiduciary or intrinsic? Schweizerische Numismatische Rundschau 84, 93-123.

Christiansen, E. (2004) Coinage in Roman Egypt. The Hoard Evidence. Aarhus: University of Aarhus Press.

Craddock, P. T. (1995) Early Metal Mining and Metal Production. Edinburgh: Edinburgh University Press.

- and Giumlia-Mair, A. R. (1988) Problems and possibilities for provenancing bronzes by chemical composition. Pp. 318-27 in J. E. Curtis (ed.), Bronzeworking Centres of Western Asia c. 1000539 BC. London: British Museum Press.

Dayton, J. E. (1993) The Discovery of Glass: Experiments in the Smelting of Rich, Dry Silver Ores, and the Reproduction of Bronze Age-type Cobalt Blue Glass as a Slag. Cambridge, Mass.: Harvard University. 
DeJesus, P. S. (1980) The Development of Prehistoric Mining and Metallurgy in Anatolia. British Archaeological Reports International Series 74. Oxford.

Gilmore, P. (1980) The Latin legend tetradrachms of Nero. P. 210 in Spink's Numismatic Circular.

Gitler, H. and Ponting, M. (2003) The Silver Coinage of Septimius Severus and his Family (AD 193-211). Collana di Studi e Richerche di Numismatica, 16. Milan: Ennere.

Hoover, O. D. (2004) Anomalous tetradrachms of Philip I Philadelphus struck by Autonomous Antioch. Schweizer Münzblätter 214 (June), 31-35.

Levy, B. E. (1993) Tyrian shekels and the First Jewish War. Pp. 267-74 in Proceedings of the Eleventh International Numismatic Congress, Brussels, 1991. Louvain-la-Neuve: Séminaire de Numismatique Marcel Hoc.

- (1995) Tyrian shekels: The MYTH of the Jerusalem Mint. Society for Ancient Numismatics 19/2, 33-35.

- (2005) Later Tyrian shekels. Pp. 885-90 in XIII Congreso International de Numisática, Actas, Madrid 2003. Madrid: Numismatica Madrid.

Lönnqvist, K. (2007) The Report of the Amman Lots of the Qumran Silver Coin Hoards. Amman: National Press.

McAlee, R. G. (1999) The Livia hoard of Pseudo-Philip tetradrachms. American Journal of Numismatics 11, 1-12.

Meshorer, Y. (2001) A Treasury of Jewish Coins from the Persian Period to Bar Kokhba. Jerusalem: Yad Ben-Zvi Press.
Newell, E. T. (1919) The pre-Imperial coinage of Roman Antioch. Numismatic Chronicle 19, 69-113.

Prieur, M. and Prieur, K. (2000) A Type Corpus of the Syro-Phoenician Tetradrachms and their Fractions from 57 BC to $A D 253$. Lancaster, Pennsylvania and London: Classical Numismatic Group.

Sydenham, E. A. (1933) The Coinage of Caesarea in Cappadocia. London: Spink and Son.

Tylecote, R. F., Ghaznavi, H. A. et al. (1977) Partitioning of trace elements between the ores, fluxes, slags and metal during the smelting of copper. Journal of Archaeological Science 4, 30533.

Walker, D. R. (1976) The Metrology of the Roman Silver Coinage, Part I: From Augustus to Domitian. Oxford: British Archaeological Reports.

Weiser, W. and Cotton, H. M. (1996) 'Gebt dem Kaiser, was des Kaisers ist ...’ Die Geldwährungen der Griechen, Juden, Nabatäer und Römer im syrisch-nabatäischen Raum unter besonderer Berücksichtigung des Kurses von Sela' /Melaina und Lepton nach der Annexion des Königreiches der Nabatäer durch Rom. ZPE $114,237-87$.

- (2002) Neues zum 'tyrischen Silbergeld': herodianischer und römischer Zeit. ZPE 139, 235-50.

Woytek, B. E., Uhlir, K., Alram, M., Schreiner, M. and Griesser, M. (2007) The Denarius under Trajan: New Metallurgical Analyses. Numismatic Chronicle 167, 147-63. 